Post-print version of article published in

European constitutional law review, 2018,

Vol. 14, No. 1, pp. 231-259

DOI : $10.1017 /$ S1574019617000402

\title{
Shaping EU Trade Policy post-Lisbon: Opinion 2/15 of 16 May 2017
}

Marise Cremona*

\section{Introduction: the context and significance of the Opinion}

On 16 May 2017 Opinion 2/15 was delivered by the full Court, in response to a request by the Commission pursuant to Article 218(11) TFEU. ${ }^{1}$ According to that provision, which is found in the Article dealing with the negotiation and conclusion of international agreements by the European Union, '[a] Member State, the European Parliament, the Council or the Commission may obtain the opinion of the Court of Justice as to whether an agreement envisaged is compatible with the Treaties'. Although the request is for an 'opinion', Article 218(11) TFEU also provides that '[w]here the opinion of the Court is adverse, the agreement envisaged may not enter into force unless it is amended or the Treaties are revised'; it therefore has a binding legal effect.

The 'agreement envisaged' in this case was the free trade agreement that had been negotiated between the EU and Singapore ('the Singapore Agreement'). The gestation of this agreement had been long: the original authorisation to negotiate had been granted by the Council in 2006 and envisaged a region-to-region agreement with ASEAN as a group. ${ }^{2}$ However the Council also envisaged the possibility of reverting to bilateral agreements with individual ASEAN states, and this is in fact what happened: the ASEAN negotiations were paused and on 22 December 2009 - as the Court points out, a few weeks after the Lisbon Treaty came into force - the Council authorised the Commission to start negotiations with Singapore. ${ }^{3}$ In 2011 the negotiating directives were amended to include investment and in June 2015 the text was initialled. The agreed text assumes that the Singapore Agreement will be concluded by the EU alone, rather than by the EU and its member states as a 'mixed' agreement. ${ }^{4}$ The Council and member states were, however, not convinced that as the Commission argued - the whole agreement fell within exclusive EU competence; they thought the agreement contained elements of shared competence and indeed elements falling within exclusive member state competence, and that it should therefore be mixed.

Similar discussions were taking place over other negotiations as the EU sought to conclude a new generation of trade and investment agreements with (among others) Canada and the USA. In fact, the Singapore agreement is an example - and not the most controversial - of these new 'deep and comprehensive' trade agreements that represent the core of EU trade policy, and the Court's Opinion is thus important not only for the future of the Singapore Agreement itself, but for future

\footnotetext{
*Emeritus Professor, European University Institute.

${ }^{1}$ Opinion 2/15 of 16 May 2017, ECLI:EU:C:2017:376; opinion of Advocate General Sharpston delivered on 21 December 2016, ECLI:EU:C:2016:992.

2 The Association of South East Asian Nations (Brunei Darussalam, Myanmar/Burma, Cambodia, Indonesia, Laos, Malaysia, Philippines, Singapore, Thailand and Vietnam).

${ }^{3}$ Negotiations were also opened with Vietnam (the text of a free trade agreement was finalised in February 2016) and Malaysia, Thailand, Philippines and Indonesia.

${ }^{4}$ The text to the Singapore Agreement agreed in 2015 was stated to be simply between the European Union and the Republic of Singapore, i.e. a non-mixed agreement. Were a bilateral agreement of this type to be mixed it would be concluded by the EU and its member states 'of the First Part' and by the third country 'of the Second Part'.
} 
trade agreements (including a possible future EU-UK agreement). The current wave of negotiations date from the 'Global Europe' Trade Strategy adopted in 2006, ${ }^{5}$ when the EU decided to reinvigorate its programme of trade liberalisation based on bilateral agreements with important trading partners. This was a response both to failures to progress multilateral negotiations within the WTO and to the decision by the USA to pursue major regional free trade agreements, especially in the Asia-Pacific. ${ }^{6}$ In addition to the traditional liberalisation of trade in goods these recent agreements aim to extend WTO commitments on trade in services and enforcement of intellectual property rights, and to improve regulatory cooperation. They have also featured chapters on trade and sustainable development, which link trade liberalisation to commitments to internationally-agreed goals and standards of environmental protection, renewable energy and core labour rights. ${ }^{7}$ Since the coming into force of the Lisbon Treaty, the Union has also added investment, both market access and investor protection, and in some cases (including the Singapore Agreement) investor-state dispute settlement (ISDS). The potential impact of investor protection and ISDS on the regulatory autonomy of the EU and its member states has proved controversial and has given rise to highly visible civil society campaigns ${ }^{8}$ and political debate. ${ }^{9}$ Alongside the political debates, legal debates have taken place over the compatibility with EU law of the provision in the recent agreements for ISDS either, traditionally, via arbitration (as in the Singapore Agreement) or via the establishment of an investment court (as in the agreements with Vietnam and Canada).

Legal debate has also centred on the distribution of competence to conclude these new extensive trade agreements. This involves the extent of the post-Lisbon common commercial policy (CCP), a matter of a priori exclusive competence as a result of Article 3(1) TFEU, ${ }^{10}$ and in particular the extent to which the CCP covers investment protection; but also concerns the consequences of including chapters on trade and sustainable development: could these chapters be subsumed under CCP powers or did they need a separate legal basis? This group of questions over competence are at the heart of Opinion 2/15. ${ }^{11}$ The Commission's request was restricted to the question of competence, and conspicuously omitted any question as to substantive compatibility:

'Does the Union have the requisite competence to sign and conclude alone the Free Trade Agreement with Singapore? More specifically,

1. Which provisions of the agreement fall within the Union's exclusive competence?

\footnotetext{
${ }^{5}$ European Commission, 'Global Europe: Competing in the World', COM(2006) 567, 4 October 2006.

${ }^{6}$ Since 2006 free trade agreements have been negotiated with South Korea, Singapore, Colombia, Peru and Ecuador, Ukraine, Georgia, Moldova and Vietnam, as well as Canada (the Comprehensive Trade and Economic Agreement, or 'CETA') and Japan. Other ongoing negotiations include the currently stalled Transatlantic Trade and Investment Partnership Agreement ('TTIP') with the USA.

${ }^{7}$ See European Commission, 'Trade for all - Towards a more responsible trade and investment policy', 14 October 2015.

${ }^{8}$ See for example the European Citizens Initiative 'Stop TTIP', at issue in case T-754/14 Michael Efler and Others v European Commission, EU:T:2017:323.

${ }^{9}$ For example, the difficulty over the signature of the CETA following the initial refusal of assent by the Regional Parliament of Wallonia in Belgium.

${ }^{10}$ Article 3(1) TFEU provides that 'The Union shall have exclusive competence in the following areas: ...(e) common commercial policy.'

${ }^{11}$ Although Article 218(11) TFEU refers to the compatibility of an envisaged agreement with the Treaties it has been recognised since the first such Opinion that this determination may also cover issues of competence: Opinion 1/75, EU:C:1975:145.
} 
2. Which provisions of the agreement fall within the Union's shared competence? and

3. Is there any provision of the agreement that falls within the exclusive competence of the Member States? ${ }^{\prime 12}$

That these questions were regarded as important, not only for the Singapore agreement itself but also as setting a precedent for the negotiation and conclusion of the next generation of EU trade agreements can be seen from the fact that 25 member states submitted observations. ${ }^{13}$ In its Opinion the Court (and in her opinion, the Advocate General ${ }^{14}$ ) focus strictly on the question of competence. Three times the Court repeats that its Opinion in this case is without prejudice to the issue of compatibility ${ }^{15}$ it cannot therefore be assumed that the absence of discussion is a sign that the Court considers that there are no compatibility problems - perhaps indeed rather the contrary. That the Court was well aware that compatibility has been debated, in particular with respect to the provisions on ISDS, is clear from the fact that one of its reminders that its findings are without prejudice to compatibility occurs in the passage of the Opinion which discusses competence in relation to ISDS. ${ }^{16}$ And indeed, since the handing down of Opinion 2/15, a new request under Article 218(11) TFEU has been made, this time by Belgium, with respect to the EU-Canada Comprehensive Economic and Trade Agreement (CETA) asking whether the ISDS provisions of the CETA are 'compatible with the Treaties, including fundamental rights'. ${ }^{17}$

The following comments on Opinion 2/15 will therefore not discuss the compatibility of ISDS with the EU Treaties, ${ }^{18}$ but it should be borne in mind that the Opinion does not settle all legal questions arising from this latest generation of trade and investment agreements. Nevertheless, it is an important Opinion. The increased political salience of trade agreements in a world of antiglobalisation and challenges to the post-war Western consensus in favour of trade liberalisation means that the issue of who ultimately gets to decide on EU trade policy, and especially the conclusion of trade agreements, is no longer a purely academic or technical question. Indeed although the Court has always taken the view that procedural (or political) complications should not drive the determination of competence, ${ }^{19}$ it is clear that the design of trade agreements is being

\footnotetext{
12 Opinion 2/15, para 1.

${ }^{13}$ Only Estonia, Croatia and Sweden did not submit observations.

${ }^{14}$ In French, avis is used for the Court's Opinion and conclusions for that of the Advocate General. It is somewhat confusing that in English the term 'opinion' is used for both; at times 'view' has been used to describe the Advocate General's opinion (see e.g. the View of AG Kokott in Opinion procedure 2/13, ECLI:EU:C:2014:2475), but the official Court reports now use 'opinion'. In what follows Opinion (capitalized) will refer to that of the Court of Justice and opinion (lower case) will refer to that of the Advocate General. ${ }^{15}$ Opinion 2/15, paras 30, 290, 300.

${ }^{16}$ Opinion 2/15, para 290.

17 Opinion 1/17, pending, request filed 7 September 2017.

${ }^{18}$ Much has been written on this issue; see e.g. G Bermann, 'Navigating EU Law and the Law of International Arbitration' (2012) 28 Arbitration International 397; M Burgstaller, 'Investor-State Arbitration in EU International Investment Agreements with Third States' (2012) 39 Legal Issues of Economic Integration 207; S Hindelang, 'The Autonomy of the European Legal Order - EU Constitutional Limits to Investor-State Arbitration on the Basis of Future EU Investment-related Agreements' in M Bungenberg and C Herrmann (eds), Common Commercial Policy after Lisbon, Special Issue to the European Yearbook of International Economic Law, Springer, 2013, 187; C Herrmann, 'The role of the Court of Justice of the EU in the emerging EU Investment Policy' (2014) 15 Journal of World Investment \& Trade 570.

${ }^{19}$ See in particular Opinion 1/94, EU:C:1994:384, where the Court, in response to a Commission argument that 'The Community's unity of action vis-à-vis the rest of the world will thus be undermined and its negotiating
} 
shaped by the implications of including chapters which fall within shared competence and where Member State participation is very likely, ${ }^{20}$ even if not legally required, with all that means in terms of the political uncertainties of ratification. ${ }^{21}$ Opinion $2 / 15$ was thus eagerly awaited, as the Court's determination of the boundaries of exclusive EU competence will certainly be a factor in deciding on the content of future trade agreements, and especially the inclusion of investment protection and ISDS. More prosaically perhaps, Opinion 2/15 forms an important part of the Court's interpretation of the Lisbon Treaty's codification of EU law on external competence; not only the interpretation of the (enlarged) scope of the CCP but also the application of Article 3(2) TFEU on exclusivity as regards external agreements, and the basis on which external powers may be derived from internal competence-conferring provisions. In this it forms part of a broader picture and indeed case law since Opinion 2/15 was delivered has already added to, and nuanced, the picture. ${ }^{22}$

\section{The Opinion: a summary}

The Opinion is long and complex, and the opinion of Advocate General Sharpston even longer, at 570 paragraphs, with an Annex containing a 131 paragraph summary of the Singapore Agreement. In this note I highlight those parts of the Advocate General's opinion where she takes a different view from that of the Court, but the opinion as a whole repays close reading; in particular, the first part of the opinion offers a clear and succinct summary of the relationship between internal and external competence and legal basis, the conditions under which exclusive competence arises, and the 'state of the art' in understanding them in the light of pre- and post-Lisbon case law. ${ }^{23}$ In the following sections I will comment on some key aspects of the ruling: the scope of the EU's common commercial policy and the role played by the general external objectives established in the EU Treaties; the application of the conditions for exclusive external competence set out in Article 3(2) TFEU; whether shared competence necessarily implies mixity (the conclusion of the agreement by the member states and EU jointly); the question of the member states' bilateral investment treaties; and competence in relation to ISDS. But first I will give a general orientation by briefly summarising the Court's Opinion.

The Advocate General and the Court came to the same conclusion in fine: that the Singapore Agreement does not fall wholly within the EU's exclusive competence. They also agreed on a central question: that non-direct foreign investment, including portfolio investment, falls outside the CCP and is currently a matter of shared competence. However there are also significant differences of approach and in their conclusions. The Advocate General found greater areas of shared competence

\footnotetext{
power greatly weakened' if the WTO agreements were concluded as mixed agreements, said at para 107, 'In response to that concern, which is quite legitimate, it must be stressed, first, that any problems which may arise in implementation of the WTO Agreement and its annexes as regards the coordination necessary to ensure unity of action where the Community and the Member States participate jointly cannot modify the answer to the question of competence, that being a prior issue. ... [R]esolution of the issue of the allocation of competence cannot depend on problems which may possibly arise in administration of the agreements.'

${ }^{20}$ See note 28.

${ }^{21}$ On the legal issues surrounding the ratification of mixed agreements, see further $\mathrm{G}$ Van der Loo and $\mathrm{R}$ A Wessel, 'The non-ratification of mixed agreements: Legal consequences and solutions' (2017) 54 Common Market Law Review, 735.

${ }^{22}$ See for example C-600/14 Germany v Council, EU:C:2017:935; see further below.

${ }^{23}$ See in particular paras 54-81, 90-94 and 117-131.
} 
in the agreement, and even one clause (on the termination of Member State bilateral investment treaties) that in her view was not within EU competence at all, but was an exclusive Member State competence. The Court of Justice held that all aspects of the agreement fell within exclusive EU competence - on the basis either of Article 3(1)(e) TFEU (the CCP) or of Article 3(2) TFEU - except for (i) the provisions on investment protection insofar as they relate to non-direct investment; (ii) institutional and dispute-settlement provisions insofar as they relate to non-direct foreign investment; and (iii) the provisions on ISDS.

Building upon its earlier post-Lisbon judgments on the scope of the CCP, ${ }^{24}$ in Opinion $2 / 15$ the Court was willing to find a sufficiently close link to the agreement's trade objectives for a variety of clauses - including, crucially, the chapter on sustainable development - to be encompassed by the CCP. In this the Court was more explicit than it had been before as to the impact of the general external objectives on the nature of the Union's trade policy. The Court also gave a relatively expansive application of the test for exclusivity found in Article 3(2) TFEU, more specifically the final limb of that provision: that the (provision in the) agreement 'may affect common rules or alter their scope', finding this condition satisfied more easily than the Advocate General. As a result a wide-ranging trade and investment agreement was found to fall within exclusive EU competence - all except certain specific provisions on non-direct investment protection and on ISDS. It is not surprising that a number of commentators have suggested that the Court is effectively inviting the Commission to alter tactic, removing provisions on investment protection (or non-direct investment protection) and ISDS from trade agreements and placing them into separate agreements. ${ }^{25}$ The main trade agreement could then be concluded under exclusive powers; the (politically more controversial) investment protection / ISDS agreement would need to be concluded as a mixed agreement and would, as well as taking much longer to ratify, require explicit political commitment from each Member State.

It is notable, nevertheless, that the Court itself makes no such suggestions. It does not engage even tangentially with the practical issues surrounding its conclusion that the Singapore Agreement falls within shared competence and the implications of mixity. ${ }^{26} \mathrm{In}$ fact, as has been pointed out by Kleimann and Kübeck, ${ }^{27}$ the Court is even somewhat coy in its final conclusions: it concludes that aspects of the agreement fall within exclusive EU competence, and other aspects within shared competence, but it does not in terms answer the Commission's main question: does the EU have the requisite competence to conclude this agreement alone? Whether mixity is indeed required (as opposed to an option) in cases of shared competence is a question raised by the Opinion, and will be discussed further below; but it is at least clear that the Court was aware that the choice of the member states was in favour of mixity for these politically significant agreements. ${ }^{28}$ In the Advocate

\footnotetext{
${ }^{24}$ C-414/11 Daiichi Sankyo Co. Ltd, EU:C:2013:520; C-137/12 Commission v Council, EU:C:2013:675.

${ }^{25}$ See e.g. D Kleimann and G Kübek, 'The Singapore Opinion or the End of Mixity as We Know It', VerfBlog, 23 May 2017, http://verfassungsblog.de/the-singapore-opinion-or-the-end-of-mixity-as-we-know-it/. A Roberts, 'A Turning of the Tide against ISDS?’ EJIL: Talk!, 19 May 2017, https://www.ejiltalk.org/a-turning-of-the-tideagainst-isds/.

${ }^{26}$ C.f. note 19.

${ }^{27}$ D Kleimann and G Kübek, note 25.

${ }^{28}$ All the member states submitting observations argued that the EU should not conclude the Singapore Agreement alone and this was also clear from discussions in Coreper ( $A G$ 's opinion, para 7). In fact, the original negotiating directives had specified a mixed agreement ( $A G^{\prime}$ 's opinion, para 83). In addition, the Council had
} 
General's opinion mixity was required because one clause in her view fell within exclusive Member State competence; she alludes to the difficulties of mixed agreements and to the options available, including splitting the agreement, but as she rightly says, these are not factors which can or should influence the determination of competence. ${ }^{29}$

Let us now turn to the main issues in the case.

\section{The scope of the common commercial policy}

At the centre of this case was the scope of the post-Lisbon common commercial policy, and the extent to which this legal basis can encompass the wide-ranging provisions of a modern trade agreement..$^{30}$ The Lisbon Treaty had brought within the scope of exclusive trade competence, trade in services, the 'commercial aspects' of intellectual property and foreign direct investment. ${ }^{31}$ Earlier judgments had established the Court's approach to interpreting the scope of the post-Lisbon CCP in relation to trade in services ${ }^{32}$ and the commercial aspects of intellectual property. ${ }^{33}$ This approach has focused not on attempts to define these terms in the abstract, but rather on identifying the scope of the CCP as a policy concerned with international trade (i.e. trade with non-member states). CCP measures, the Court has said, must have a 'specific link' with international trade, in that they are intended to 'promote, facilitate or govern' trade and have 'direct and immediate effects' on trade. ${ }^{34}$ And in seeking to distinguish between measures falling within the CCP and those which should properly be based on other powers, such as the internal market, the Court has recognised that harmonisation of the laws of the member states is not a matter for the CCP; the CCP can however be used in order to extend to third countries standards currently applicable within the EU as a result of internal market legislation. ${ }^{35}$ This approach to the CCP underlies, and is reinforced by, Opinion 2/15. The Court summarises its earlier case law in a paragraph which it subsequently refers back to several times:

'It is settled case-law that the mere fact that an EU act, such as an agreement concluded by it, is liable to have implications for trade with one or more third States is not enough for it to be concluded that the act must be classified as falling within the common commercial policy. On the other hand, an EU act falls within that policy if it relates specifically to such trade in

\footnotetext{
insisted on the EU-Canada CETA, similar in terms of scope to the Singapore Agreement, being signed and concluded as a mixed agreement.

${ }^{29}$ AG's opinion, paras 76-77 and paras 565-569, where she mentions the potential risk of a Member State failing to ratify a mixed agreement, warning that were the reasons for such a refusal to relate to aspects of the agreement falling within exclusive EU competence the Member State would be in breach of its Treaty obligations.

${ }^{30}$ For general comment on the CCP as revised by the Lisbon Treaty, see M Krajewski, 'The Reform of the Common Commercial Policy' in A Biondi, P Eeckhout \& S Ripley (eds) EU Law After Lisbon OUP 2011; M Cremona, 'A Quiet Revolution: The Common Commercial Policy Six Years after the Treaty of Lisbon,' Swedish Institute for European Policy Studies, Working Paper 2017:2.

${ }^{31}$ Although trade in services and the commercial aspects of intellectual property have formed part of the CCP since the Nice Treaty, they were largely excluded from exclusive competence.

${ }^{32}$ C-137/12 Commission v Council, EU:C:2013:675.

${ }^{33}$ C-414/11 Daiichi Sankyo Co. Ltd, note 24; Opinion 3/15, EU:C:2017:114.

${ }^{34}$ C-414/11 Daiichi Sankyo Co. Ltd, paras 50-52; C-137/12 Commission v Council, paras 56-58.

${ }^{35}$ C-414/11 Daiichi Sankyo Co. Ltd, paras 59-60 ; C-137/12 Commission v Council, paras 64-67.
} 
that it is essentially intended to promote, facilitate or govern such trade and has direct and immediate effects on it ... ${ }^{36}$

Applying this test to the provisions on market access, the Court had no difficulty in finding that chapters 2-6 of the Singapore Agreement, which concern trade in goods, as well as chapter 7 on non-tariff barriers to trade and investment in renewable energy generation and chapter 10 on public procurement, fell within the CCP. ${ }^{37}$ In relation to trade in services (chapter 8 ), the Court explicitly confirmed that all modes of supply of services fall within the $\mathrm{CCP} ;{ }^{38}$ and that the only remaining sectoral exclusion is that of agreements 'in the field of transport', which according to Article 207(5) TFEU (continuing an exception introduced by the Treaty of Nice) are governed by the Treaty provisions relating to the common transport policy. ${ }^{39}$ The provisions on transport services in chapter 8 of the Singapore Agreement do not therefore fall within CCP-based exclusive competence and were considered by the Court later in its Opinion, in considering exclusive competence on the basis of Article 3(2) TFEU.

In examining the Singapore Agreement's chapter on intellectual property rights, the Court first affirms that the 'commercial aspects' of intellectual property in Article 207 TFEU refers to those aspects which satisfy the test of possessing a 'specific link' to international trade. The different provisions on intellectual property in the Singapore Agreement consist of 'first, a reminder of existing multilateral international obligations and, secondly, bilateral commitments'. ${ }^{40}$ The purpose of these provisions, and those dealing with enforcement of intellectual property rights and counterfeit and pirated goods, is to guarantee entrepreneurs in both parties an 'adequate level' of protection of their rights, so as to ensure 'a degree of homogeneity' in standards of protection of intellectual property rights and enforcement. ${ }^{41}$ This latter phrase allows the Court to argue that the intellectual property provisions are about 'increas[ing] the benefits from trade and investment' and liberalisation of trade, ${ }^{42}$ but are 'in no way' about harmonisation. ${ }^{43}$

Chapter 9 of the Singapore Agreement on investment protection provided the first opportunity since the Lisbon Treaty reform for the Court to address the question of the application of the CCP to foreign direct investment. Here again the Court applies the 'direct and immediate effects on trade' test. In a first step, a distinction is made between foreign direct investment and other forms of

\footnotetext{
${ }^{36}$ Opinion 2/15, para 36.

${ }^{37}$ With the exception of those aspects of chapter 10 which concern procurement in relation to transport services.

${ }^{38}$ Opinion 2/15, para 54. The Court referred to the earlier (pre-Lisbon) Opinion 1/08, EU:C:2009:739, concluding that although the Treaty terminology in French has altered from 'commerce des services' to 'échanges de services' (the English in both cases being 'trade in services') the meaning of these terms is 'essentially identical' and no distinction is made between different modes of supply. The distinction made in Opinion 1/94, EU:C:1994:384, between mode 1- cross-border supply - and other forms of trade in services, is no longer relevant as far as the scope of the CCP is concerned.

${ }^{39}$ Opinion 2/15, paras 56-68. This includes all four modes of supply of transport services, as well as services 'inherently linked' to transport services. However the Court held that aircraft repair and maintenance services and the sale or reservation of air transport services are included within the CCP since they are not inherently linked' to air transport; the AG, in contrast, had taken the view that these services were 'indissociably linked to transport': opinion of AG Sharpston, paras 191 and 218.

${ }^{40}$ Opinion 2/15, para 121.

${ }^{41}$ Opinion 2/15, paras 122-124.

42 Opinion 2/15, para 125.

${ }^{43}$ Opinion 2/15, para 126.
} 
foreign investment. Unsurprisingly, the Court found that the express qualification of 'direct' investment in the Treaties meant that the drafters had wished to exclude other - non-direct foreign investment; it then turned to earlier case law interpreting 'direct investment' in the context of the movement of capital, to the effect that

'direct investment consists in investments of any kind made by natural or legal persons which serve to establish or maintain lasting and direct links between the persons providing the capital and the undertakings to which that capital is made available in order to carry out an economic activity. ${ }^{44}$

This includes the acquisition of shareholdings in a company where the holding enables the shareholder 'to participate effectively in the management of that company or in its control'. ${ }^{45}$ The Court here established a parallel between 'direct investment' in internal and external contexts. However, it then brings the external dimension into focus by saying that this type of direct investment meets its 'direct and immediate effects on trade' criteria; indeed this definition of foreign direct investment, although taken from an internal context, is justified on the ground that it reflects the scope of the CCP:

'[A]ny EU act promoting, facilitating or governing participation - by a natural or legal person of a third State in the European Union and vice versa - in the management or control of a company carrying out an economic activity is such as to have direct and immediate effects on trade between that third State and the European Union, whereas there is no specific link of that kind with trade in the case of investments which do not result in such participation. ${ }^{.46}$

The same criterion is then used to argue that the CCP may cover all measures which impact foreign direct investment: not only those concerned with market access, but also those which concern investment protection (the subject of chapter 9 of the Singapore Agreement) including fair and equitable treatment and protection against expropriation without compensation. Arguments that only market access falls within the CCP are rejected. ${ }^{47}$ The provisions on investment protection 'are such as to have direct and immediate effects on that trade, since they concern the treatment of the participation of entrepreneurs of one Party in the management or control of companies carrying out economic activities in the territory of the other Party'48; each 'contributes to the legal certainty of investors' and meets the CCP test:

'The establishment of such a legal framework is intended to promote, facilitate and govern trade between the European Union and the Republic of Singapore, within the meaning of the case-law recalled in paragraph 36 of this opinion. ${ }^{49}$

In places the investment protection measures refer to areas of national law such as public order, public security, taxation and criminal law. Although these were argued to fall within Member State

\footnotetext{
${ }^{44}$ Opinion 2/15, para 80.

${ }^{45} \mathrm{Ibid}$.

${ }^{46}$ Opinion 2/15, para 84.

${ }^{47}$ As they had been in relation to goods in Opinion 1/94, EU:C:1994:384, and in relation to services in C-137/12 Commission v Council, EU:C:2013:675.

${ }^{48}$ Opinion 2/15, para 95.

${ }^{49}$ Opinion 2/15, para 94; for para 36 see above at note 36.
} 
powers, the Court held - in line with its own case law on property ownership, taxation and intellectual property in an internal context - that the Singapore Agreement's requirements deal rather with how those powers are exercised. The provision in question

'does not encroach upon the competences of the Member States regarding public order, public security and other public interests, but obliges the Member States to exercise those competences in a manner which does not render the trade commitments entered into by the European Union ... redundant'. ${ }^{50}$

Likewise, the provision on expropriation does not impinge on Member State powers as regards property ownership (c.f. Article 345 TFEU); member states are free to exercise those competences, as long as they do so 'in compliance with general principles and fundamental rights, in particular with the principle of non-discrimination' ${ }^{51}$

The Opinion therefore answers a number of questions on the scope of the CCP as regards foreign direct investment. The relatively inclusive approach is based on the 'direct and immediate effects on trade' test which is now well-entrenched and will be the starting point in future cases raising the scope of the CCP. Its mode of application by the Court in the Opinion gives an impression of inevitability of outcome: it is presented as obvious that some provisions have a 'specific link' to trade, while others do not. It is, however, a test which in fact allows the Court a great deal of room for manoeuvre in its application, as its reasoning in relation to investment and to intellectual property protection demonstrates..$^{52}$ That means that it will not necessarily be easy to take an objective view of how it should be - and would be - applied in a specific case; it is a test which favours flexibility over predictability. This may be pragmatic and desirable in a test which as well as covering the existing very varied provisions in trade agreements on goods, services, intellectual property and foreign direct investment will need to adapt to new types of trade agreement. But it does not necessarily provide certainty in future cases: we may have an answer for specific types of clauses in current trade agreements, but disputes as to the application of the test in different contexts are likely to end in further litigation. ${ }^{53}$ And the Court will need to be careful in presenting its reasoning so that over time a coherent picture is able to emerge.

\section{Sustainable development and trade - the importance of general external objectives}

We have so far examined those aspects of the Opinion where the Court draws the boundaries of what may legitimately fall substantively within the references in Article 207 TFEU to goods, services, intellectual property and foreign direct investment. But there is another equally important aspect to the extent of the CCP as a legal basis, which relates to the ability of a trade agreement to include provisions designed to achieve non-economic objectives. A classic approach would be to ask whether such provisions are simply ancillary or incidental to the predominant trade objectives or

\footnotetext{
${ }^{50}$ Opinion 2/15, para 103.

${ }^{51}$ Opinion 2/15, para 107.

52 D Kleimann, 'Reading Opinion 2/15 : Standards of Analysis, the Court's Discretion, and the Legal View of the Advocate General' [2017] EUI RSCAS Working Paper 2017/23.

${ }^{53}$ For example, see case C-389/15 Commission v Council, EU:C:2017:798, on the Lisbon Agreement on Appellations of Origin and Geographical Indications.
} 
whether they impose independent obligations sufficiently substantive to constitute a distinct objective requiring a separate legal basis..$^{54}$ In a clear departure from the opinion of the Advocate General the Court found that the provisions of chapter 13 of the Singapore Agreement, headed 'trade and sustainable development', also met the conditions of having a specific link to international trade, and direct and immediate effects on trade, and could indeed be seen as an integral part of trade policy. They could thus legitimately also be based on Article 207 TFEU, even though they do not appear to be trade instruments in the traditional sense. There are essentially two parts to the Court's argument.

The first redefines the proper objectives of EU trade policy in the light of the general objectives and principles which are to govern all external action and the explicit injunction that trade policy must be conducted 'in the context of' these principles and objectives. ${ }^{55}$ Relying on Article 21 TEU (which includes sustainable development among the EU's external objectives), Articles 205 and 207(1) TFEU as well as Articles 9 and 11 TFEU (referring to the integration of social protection and environmental protection requirements into all EU policies and activities 'with a view to promoting sustainable development'), the Court concludes that 'the objective of sustainable development henceforth forms an integral part of the common commercial policy'. ${ }^{56}$ This is a significant move, signalling that the Court is willing to take seriously the catalogue of general external objectives in Article 21 TEU as well as the reference to 'free and fair trade' in Article 3(5) TEU, as complementary to and capable of influencing the objective of trade liberalisation spelled out in Article 206 TFEU. ${ }^{57}$ As a result, the broader objectives of the Singapore Agreement could be subsumed under the umbrella of trade policy, without needing to be categorised as ancillary or incidental to the predominant purpose. The Advocate General took a different position; while recognising the importance of the general external objectives, she insisted that Articles 3(5) and 21 TEU and Articles 9 and 11 TFEU, although potentially affecting the compatibility of EU action with the Treaties, 'cannot affect the scope of the common commercial policy laid down in Article 207 TFEU' or 'modify the scope of the European Union's competence'. ${ }^{58}$

In a second step, the Court examined the different provisions in chapter 13 in the light of the established test for the CCP, based on the specific link to international trade. Here again it took a different view from the Advocate General. AG Sharpston had concluded that whereas some provisions in chapter 13 (such as those promoting climate-friendly goods and services) had a direct link to international trade, others are in themselves standard-setting, albeit by reference to other

\footnotetext{
${ }^{54}$ See e.g. C-137/12 Commission v Council, EU:C:2013:675, paras 71-72, and (in the context of development cooperation) C-377/12 Commission v Council, EU:C:2014:1903, para 39. For discussion in the context of Opinion 2/15, see D Kleimann, note 52 , at pp11-20.

${ }^{55}$ Article 207(1) TFEU.

${ }^{56}$ Opinion 2/15, para 147.

57 J Larik, 'Trade and Sustainable Development: Opinion 2/15 and the EU's Foreign Policy Objectives,' 8 June 2017, https://acelg.blogactiv.eu/2017/06/08/trade-and-sustainable-development-opinion-215-and-the-eusforeign-policy-objectives/

${ }^{58}$ Opinion 2/15, opinion of AG Sharpston, para 495. Note that at the start of her opinion the AG emphasised the agreement's multiple objectives: 'The agreement is not a 'homogeneous agreement': it does not cover one particular area or subject matter nor does it pursue a single objective. It seeks to achieve, in particular, liberalisation of trade and investment and guarantees certain standards of protection in a manner that reconciles economic and non-economic objectives.' (opinion of AG Sharpston, para 3). The Court, in contrast, defined the agreement from the start as essentially concerned with trade (Opinion 2/15, para 32) and then, as we have seen, interpreted trade objectives broadly to cover sustainable development.
} 
treaties such as ILO Conventions and multilateral environmental agreements which both the EU and Singapore have ratified. In her view these commitments 'essentially seek to achieve in the European Union and Singapore minimum standards of (respectively) labour protection and environmental protection, in isolation from their possible effects on trade. Those provisions therefore clearly fall outside the common commercial policy'. ${ }^{59}$

The Court, following the line of reasoning it had applied to intellectual property conventions, took a different view of these commitments. Far from being separate from the trading relationship, they are part of it; indeed, chapter 13 'plays an essential role in the envisaged agreement'. ${ }^{60}$ The parties 'undertake, essentially, to ensure that trade between them takes place in compliance with the obligations that stem from the international agreements concerning social protection of workers and environmental protection to which they are party. ${ }^{61}$ These references do not, it held, turn the commitments they contain into new commitments under the Singapore Agreement: 'Chapter 13 concerns neither the scope of the international agreements to which it refers nor the competences of the European Union or the member states relating to those agreements'. ${ }^{62}$ They do not therefore require a separate legal basis. On the other hand, the Court argued, the Chapter 13 commitments do display a specific link with trade between the EU and Singapore. The Singapore Agreement seeks to ensure that the implementation of both sets of commitments (the trade commitments in the Singapore Agreement and the commitments derived from the multilateral conventions) are mutually compatible: it commits the parties, first, not to encourage trade by reducing the levels of social and environmental protection below the standards laid down by those international commitments, and second, not to apply those standards in a protectionist manner.

Further, a material breach of the sustainable development commitments could lead to a suspension of the trade liberalisation provisions. ${ }^{63}$ This somewhat surprising conclusion ${ }^{64}$ turns chapter 13 of the agreement into a form of sustainable development conditionality, potentially strengthening its effect:

'It follows from all of those factors that the provisions of Chapter 13 of the envisaged agreement are intended not to regulate the levels of social and environmental protection in the Parties' respective territory but to govern trade between the European Union and the Republic of Singapore by making liberalisation of that trade subject to the condition that the

\footnotetext{
59 Opinion 2/15, opinion of AG Sharpston, para 491, emphasis in original.

60 Opinion 2/15, para 162.

61 Opinion 2/15, para 152.

62 Opinion 2/15, para 155. Contrast here AG Sharpston: 'I cannot accept the Commission's argument that Article 13.6.2 of the EUSFTA (which requires effective implementation of the multilateral environmental agreements to which the European Union and Singapore are party) involves no new international obligation for the Parties. It is true that that provision merely refers to pre-existing multilateral commitments of the Parties concerning environmental protection. However, its effect is to incorporate those commitments into the EUSFTA and therefore make them applicable between the European Union and Singapore on the basis of the EUSFTA. Article 13.6.2 thus clearly results in a new obligation for the Parties, enforceable in accordance with the EUSFTA.' (opinion of AG Sharpston, para 498, emphasis in original)

63 Opinion 2/15, para 161; the Court here refers to general treaty law, citing Article 60(1) of the Vienna Convention, rather than any explicit provision to this effect in the Singapore Agreement.

64 The AG took the view that there was no labour or environmental standards-based conditionality in chapter 13: opinion of AG Sharpston, para 491.
} 
Parties comply with their international obligations concerning social protection of workers and environmental protection. ${ }^{65}$

Since the need to strengthen the sustainable development dimension of trade agreements has been a source of criticism of EU trade policy this development may be welcomed. ${ }^{66}$ However, as Ankersmit has pointed out, given that the Singapore Agreeement's dispute settlement procedures do not apply to chapter $13,{ }^{67}$ it is not clear how this possibility of suspension would work in practice. ${ }^{68}$ One may also point out that if the possibility of conditionality-based suspension is taken seriously then the Court's contention that chapter 13 does not affect the scope of the obligations under the international agreements it refers to, and therefore does not impose new obligations on the parties, becomes harder to maintain. ${ }^{69}$

In defining the scope of the CCP and its relation to internal competences the Court has thus developed a distinction. The CCP may encompass clauses which refer to standards established in existing agreements binding the EU; such clauses, according to the Court, preserve the right of the parties to set their own standards in conformity with their international obligations, and in accordance with their own internal legislative procedures. ${ }^{70}$ Article 207 TFEU does not, on the other hand, provide a basis for the harmonisation of labour or environmental standards; in accordance with Article 207(6) TFEU such harmonisation would require a separate legal basis. ${ }^{71}$

\section{Exclusive external competence under Article 3(2) TFEU}

Notwithstanding the breadth of the CCP, two substantive sets of commitments in the Singapore Agreement fall outside its scope: transport services and non-direct foreign investment. In these fields, external powers must be implied from internal policy competences on the basis of Article 216(1) TFEU, and their exclusivity determined on the basis of Article 3(2) TFEU, provisions which represent an attempt to codify pre-existing case law on the existence and exclusivity of implied external competences. The basis for implied external competence is essentially two-fold. ${ }^{72}$ First, it may be based on the existence of Union acts ('common rules') which may be affected if the member states act externally independently of the EU; it is thus based on the pre-emptive rationale that derives from the AETR case. ${ }^{73}$ Second, it may be based on an effectiveness (effet utile) rationale, where an external agreement is necessary to achieve the objectives established in the Treaties. Over the years an accretion of case law has built up over these two bases for external competence, and in

\footnotetext{
${ }^{65}$ Opinion 2/15, para 166.

${ }^{66}$ See e.g. the Namur Declaration of 5 December 2016, http://declarationdenamur.eu/en/.

${ }^{67}$ Article 13.16(1) EUSFTA.

${ }^{68}$ L Ankersmit, 'Opinion 2/15: Adding Some Spice to the Trade \& Environment Debate', 15 June 2017, http://europeanlawblog.eu/2017/06/15/opinion-215-adding-some-spice-to-the-trade-environment-debate/

${ }^{69}$ C.f. opinion of AG Sharpston, para 498, note 62.

70 Opinion 2/15, para 165; C-414/11 Daiichi Sankyo Co. Ltd, paras 59-60.

71 Opinion 2/15, para 164. According to Article 207(6) TFEU, cited here by the Court, "[t]he exercise of the competences conferred by this Article in the field of the common commercial policy shall not affect the delimitation of competences between the Union and the Member States'.

${ }^{72}$ For more detail, see M Cremona, 'EU External Competence - Rationales for Exclusivity' in I Govaere and S Garben (eds), The Division of Competences between the European Union and its Member States: Reflections on the Past, Present and Future, Hart Publishing 2017.

${ }^{73}$ Case 22/70 Commission v Council, EU:C:1971:32 (AETR), paras 17-18.
} 
particular over the conditions under which common rules may be 'affected' (what is sometime referred to an the 'AETR-effect'). And the drafters of the Lisbon Treaty reflected the tendency of early case law to elide the distinction between the existence of implied external competence and its exclusivity by including in the Treaties two provisions, very similar but not identical in wording, one on the conditions under which the EU possesses the competence to conclude an external agreement (Article 216(1) TFEU), and one on the conditions under which the EU possesses an exclusive competence to conclude external agreements (Article 3(2) TFEU), with no indication as to their relationship. Thus since the Lisbon Treaty, two questions in particular have arisen: to what extent should these provisions be interpreted in line with earlier, pre-Lisbon case law? And how should we read the relationship between them? Opinion $2 / 15$ helps to settle the answers to these questions albeit with some ambiguity as regards the second, which has required a subsequent clarification. In the Opinion the Court did not take the apparently logical route of determining first the existence of competence and then deciding whether that competence is exclusive. ${ }^{74}$ Both the formulation of the Commission's question and the uneasy relationship between the two provisions led the Court to start with the issue of exclusive competence, and only where exclusivity cannot be demonstrated did it, in some instances, go on to consider the possibility of nevertheless basing a shared competence on Article 216(1) TFEU.

Article 3(2) TFEU provides three possible conditions under which external competence may be exclusive (in addition to the a priori exclusive competences listed in Article 3(1) TFEU): when the conclusion of the international agreement is provided for in a legislative act of the Union; when it is necessary to enable the Union to exercise its internal competence; and in so far as its conclusion may affect common rules or alter their scope. These are based on the two rationales already mentioned: the first and third are linked to the existence of internal EU legislation or common rules (the 'AETR-effect'); the second is the effet utile rationale. In Opinion 2/15, in line with its earlier case law, the Court first confirmed that these conditions reflect the pre-Lisbon case law, ${ }^{75}$ and that Article 3(2) TFEU should therefore be read in the light of that case law, as well as the cases on Article 3(2) TFEU that post-date the Lisbon Treaty. ${ }^{76}$ The focus in the Opinion is on the final limb of Article 3(2) TFEU - whether the provisions of the Singapore Agreement 'may affect common rules or alter their scope'. Without summarising each step of the Opinion, the following points may be noted.

First, the Court follows its own injunction to engage in 'a comprehensive and detailed analysis' ${ }^{77}$ of the different provisions of the agreement and the relevant EU legislation which may be affected. It looks at each type of transport in turn and its reasons for finding exclusive competence in each case are not identical.

Second, the EU's 'common rules' may be affected where the agreement grants rights to EU operators under different conditions from those derived from existing EU legislation. Here, in the context of maritime transport, the Court pointed out that EU nationals established in Singapore would possess maritime transport rights as a result of the Singapore Agreement without necessarily

\footnotetext{
${ }^{74}$ C.f. Opinion 1/03, EU:C:2006:81, paras 114-116.

${ }^{75}$ In particular, case 22/70 Commission v Council, note 73, and case C-467/98 Commission v Denmark, EU:C:2002:625.

${ }^{76}$ In particular, case C-114/12 Commission v Council, EU:C:2014:2151; Opinion 1/13, EU:C:2014:2303; Opinion

3/15, EU:C:2017:114.

77 Opinion 1/03, note 74, para 133.
} 
operating under an EU Member State flag; the EU regulation in question would thereby be affected. $^{78}$

Third, where an agreement provides for the application between the parties of rules that 'overlap to a large extent with the common EU rules applicable to intra-Community situations', whether or not there is any contradiction between them, that agreement may affect or alter the scope of the common rules. ${ }^{79}$ Thus provisions which essentially extend the benefits of internal market legislation to a third country are likely to satisfy the conditions for exclusive competence.

Fourth, the provisions relating to inland waterways transport services are of such limited scope that they may be disregarded without enquiring whether or not the conditions of Article 3(2) TFEU are fulfilled. ${ }^{80}$ The Court here applies in the context of exclusivity an approach, based on the distinction between predominant and incidental or ancillary purposes of an act, developed in the context of determination of legal basis. ${ }^{81}$ Provisions which are regarded as purely ancillary or of very limited scope may not require a separate legal basis; it seems logical therefore that they should not by themselves alter the competence balance of the agreement.

Finally, in considering the possible exclusivity of competence relating to non-direct foreign investment, the Court follows the Advocate General in rejecting the Commission's argument that the 'common rules' which may be affected under Article 3(2) TFEU may include rules laid down in primary EU law. Unusually (it is the only Treaty freedom to do so) Article 63 TFEU abolishes restrictions on the movement of capital between the EU and third countries as well as between EU member states, ${ }^{82}$ and the Commission argued that this is a 'common rule' which would be affected by unilateral Member State action on investment. The Court put forward two reasons for rejecting the Commission's position. The first is the case law history, what the Court refers to as 'the reasoning inherent in the rule' of the final phrase of Article 3(2) TFEU: in the AETR case, from which this rule ultimately derives, the common rules referred to were found in secondary legislation; exclusive external competence was based on the legislative exercise (and not only the existence) of an internal competence. ${ }^{83}$ While it has certainly always been assumed that the 'common rules' referred to are to be found in secondary legislation, this reasoning is not perhaps in itself completely convincing given the nature of the obligation in Article 63 TFEU. An alternative more convincing reason is suggested by the Advocate General: to derive exclusive competence directly from Article 63 would in effect be to hold that Article 63 TFEU creates an a priori exclusive competence (one that does not depend on EU action); a priori exclusivity is based on Article 3(1) not Article 3(2), and the list of such competences is closed. ${ }^{84}$ The Court's second reason is, in my view, legally stronger: an international agreement cannot 'affect' or 'alter the scope' of a Treaty rule (such as Article 63 TFEU)

\footnotetext{
78 Opinion 2/15, paras 189-190.

79 Opinion 2/15, para 201. This approach was applied to both rail and road transport services. For another example of this reasoning see case C-114/12 Commission v Council, paras 85-102.

80 Opinion 2/15, paras 216-217.

${ }^{81}$ For its use in a legal basis context, see C-137/12 Commission v Council, EU:C:2013:675, paras 70-71 (note 54).

82 Somewhat ironically, this provision was itself derived from secondary legislation: Directive $88 / 361$, no longer in force.

83 Opinion 2/15, paras 231-234; see also opinion of AG Sharpston, para 353.

${ }^{84}$ C.f. opinion of $A G$ Sharpston, para 358.
} 
since according to the hierarchy of norms in EU law, primary Treaty law takes precedence over international agreements. ${ }^{85}$

Neither the Advocate General nor the Court considered the possible application of the second limb of Article 3(2) TFEU, on the ground that the Commission did not argue the point. According to this test, competence to conclude an agreement will be exclusive when its conclusion 'is necessary to enable the Union to exercise its internal competence' ${ }^{86}$ It might indeed have been argued that in order to give full effect to the Treaty prohibition of restrictions on the movement of capital between the EU and third countries, the agreement of the third country - and thus an agreement with the third country - is necessary. The Court's explanation of this ground of exclusivity in Opinion 1/03 could well be applied to the movement of capital:

'the situation envisaged ... is that in which internal competence may be effectively exercised only at the same time as external competence ... the conclusion of the international agreement being thus necessary in order to attain objectives of the Treaty that cannot be attained by establishing autonomous rules. ${ }^{87}$

It is well-known, however, that although this ground of exclusivity continues to be mentioned by the Court, and is now enshrined in the Treaties, it has not been successfully pleaded since the ruling in Opinion $1 / 76 .{ }^{88}$ Tellingly, in the present case the Court went on (again following the Advocate General) to use the similarly-worded provision in Article 216(1) TFEU, ${ }^{89}$ together with Article 63 TFEU, as a basis for concluding that the EU possesses a shared external competence in relation to non-direct foreign investment. ${ }^{90}$ Apart from raising the question why the condition in Article $216(1)$ is satisfied while the (similar) condition in Article 3(2) is not, this step by the Court is interesting in two ways. First, while Article 216(1) TFEU codifies the pre-Lisbon case law on implied external powers, the tendency has been, in institutional practice and the Court's judgments, to omit any reference to this provision as part of the legal basis for external agreements. ${ }^{91}$ Here, an explicit reference is made to Article 216(1) but there is no suggestion that it should also be included as a legal basis. ${ }^{92}$ Second, the Court concluded that competence over non-direct foreign investment is shared, not exclusive. What are the implications of this finding for the central question asked by the Commission: does the Union have the requisite competence to sign and conclude alone the Free Trade Agreement with Singapore?

\footnotetext{
${ }^{85}$ Opinion 2/15, para 235; see also opinion of AG Sharpston, para 354.

${ }^{86}$ Article 3(2) TFEU.

${ }^{87}$ Opinion 1/03, note 74 , para 115 , referring to Opinion 1/76, EU:C:1977:63, from which this test derives.

88 Opinion $1 / 76$, note 87 .

${ }^{89}$ Article 216(1) TFEU provides that the EU has competence to conclude an international agreement (inter alia) 'where the conclusion of an agreement is necessary in order to achieve, within the framework of the Union's policies, one of the objectives referred to in the Treaties'.

90 Opinion 2/15, para 239-242.

${ }^{91}$ Article 216(1) TFEU does not establish an independent treaty-making power for the EU; it must be combined with the relevant substantive Treaty provision (such as, in this case, Article 63 TFEU).

92 In a later judgment the court has held that an explicit reference to Article 216(1) TFEU as a legal basis is not necessary as long as the substantive and procedural legal bases can be clearly determined: case C-600/14 Germany $v$ Council, EU:C:2017:935, at paras 79-92.
} 


\section{Does shared competence necessarily imply mixity?}

As we have just seen, the part of chapter 9 of the Singapore Agreement which deals with non-direct foreign investment falls within shared EU competence. The Court concluded this part of the Opinion with this surprising statement: 'It follows that Section A of Chapter 9 of the envisaged agreement cannot be approved by the European Union alone. ${ }^{93}$ As a number of commentators have pointed out, this seems to imply that shared external competence necessitates mixity. ${ }^{94}$ This would indeed be a novel outcome, overturning many years of practice, and highly significant for future EU treatymaking. Although some types of agreement are routinely concluded as mixed agreements (in particular important Association agreements), many agreements in fields of shared competence are regularly concluded by the EU alone - agreements in the fields of the Common Foreign and Security Policy, for example, as well as justice and home affairs - and this practice has never been questioned.

Certainly there may be cases (although they are likely to be rare) where competence is shared in the sense that there are parts of the agreement which fall outside EU competence altogether; here, mixity would be required. ${ }^{95}$ But where the EU possesses competence over the whole agreement albeit shared (in whole or part) with the member states, then mixity is a matter of political choice and will depend on many factors, including the political importance of the agreement. This was in fact the position assumed by the Council in this case, as also by the Advocate General. ${ }^{96}$ It seems, to say the least, unlikely that the Court would have decided to take such a decisive step without any explanation or rationale. Despite the unfortunate choice of words the Court must have meant that Member State participation could not be excluded as a matter of law, in other words that the Singapore Agreement could not be concluded by the EU alone unless the member states so decide, the latter being a political decision it could not comment on. Indeed, the member states submitting comments all argued that the EU should not conclude the Singapore Agreement alone and this was also clear from discussions in Coreper. ${ }^{97}$ The Court therefore knew that in practical terms a finding of shared competence meant that the agreement would be mixed, and this presumably influenced its choice of words. The conclusion of the Advocate General is also more nuanced: 'Since not all of those parts fall within the scope of the European Union's exclusive external competences, the EUSFTA cannot, on the basis of the European Union's exclusive competences, be concluded without the participation of the Member States. ${ }^{198}$ It should also be noted that although the Court uses the

\footnotetext{
93 Opinion 2/15, para 244.

${ }^{94} \mathrm{~L}$ Ankersmit, 'Opinion 2/15 and the Future of Mixity and ISDS', May 18 2017, https://europeanlawblog.eu/2017/05/18/opinion-215-and-the-future-of-mixity-and-isds/; G Kübeck and D Kleimann, 23 May 2017, http://verfassungsblog.de/the-singapore-opinion-or-the-end-of-mixity-as-we-knowit/; D Thym, 'Mixity after Opinion 2/15: Judicial Confusion over Shared Competences', 31 May 2017, http://verfassungsblog.de/mixity-after-opinion-215-judicial-confusion-over-shared-competences/.

95 In AG Sharpston's view this was the case for the Singapore Agreement since she held that the provision concerning member states' prior investment treaties with Singapore fell outside EU competence: see further below.

96 'At the hearing, the Council emphasised that whether the European Union or the member states exercise external competence to conclude a particular international agreement in an area of shared competence is "a political choice".' The AG goes on to say that in a case of shared competence, the Council will decide according to the procedure laid down in Article 218 TFEU whether the EU should conclude the agreement alone or with the member states (opinion of AG Sharpston, paras 74-75).

97 Opinion of AG Sharpston, para 7.

98 Opinion of AG Sharpston, para 556 (emphasis added).
} 
same form of words more than once in the Opinion, ${ }^{99}$ its operative conclusions refer simply to shared competence with no indication as to who should or could conclude the agreement. ${ }^{100}$

This reading of the troublesome phrase has now been confirmed by the Court itself, in an explanatory paragraph in a subsequent case. ${ }^{101}$ Dismissing an argument that Articles 3(2) and 216(1) TFEU are effectively coterminous (that is, that the EU only has an implied external competence where the one of the conditions set out in Article 3(2) TFEU is satisfied) the Court held:

'Admittedly the Court found, in paragraph 244 of [Opinion 2/15], that the relevant provisions of the agreement concerned, relating to non-direct foreign investment, which fall within the shared competence of the European Union and its Member States, could not be approved by the Union alone. However, in making that finding, the Court did no more than acknowledge the fact that, as stated by the Council in the course of the proceedings relating to that Opinion, there was no possibility of the required majority being obtained within the Council for the Union to be able to exercise alone the external competence that it shares with the Member States in this area. ${ }^{102}$

Although the Court here refers specifically to competence over non-direct foreign investment, its comment clearly applies to all the cases of shared competence in the Singapore Agreement; ${ }^{103}$ we will return to this point below in the context of ISDS. For now it is enough to conclude that the shortlived confusion over whether a finding of shared competence necessarily requires mixity, generated by the ambiguous wording in the Opinion, has been settled in favour of the status quo ante: in cases where the EU possesses competence over the whole of an agreement, albeit partly or wholly shared competence, mixity is not a legal requirement; it is a choice which will ultimately be made by the Council in determining the negotiating directives for the agreement.

\section{The member states' bilateral investment treaties}

The Singapore Agreement is intended to replace a number of bilateral investment treaties that some member states have concluded with Singapore. The agreement takes the unusual step of providing that Member State-Singapore bilateral investment treaties will cease to have effect on the entry into force of the Singapore Agreement and that all rights and obligations under these bilateral investment treaties will be 'replaced and superseded' by the free trade agreement. ${ }^{104}$ The Advocate General and the Court take very different views of the allocation of competence for this provision, adopting different frames of analysis; in the Advocate General's view, this clause lay within the member states' exclusive competence (and thus required their participation in the agreement); in the Court's view the clause lay predominantly within exclusive EU competence.

\footnotetext{
${ }^{99}$ See Opinion $2 / 15$, paras 282 and 304 referring respectively to transparency and dispute settlement in the context of non-direct foreign investment.

100 See Opinion 2/15, para 305.

${ }^{101}$ Case C-600/14 Germany v Council, EU:C:2017:935.

102 Ibid., at para 68.

${ }^{103}$ Shared competence over non-direct investment was specifically relied on in case C-600/14, since it does not depend on the existence of Union legislation.

${ }^{104}$ Article 9.10 EUSFTA; Article 9.10 refers in a footnote to Article 59 subparagraph 1(a) of the Vienna Convention on the Law of Treaties. There are 12 such agreements.
} 
The Advocate General's starting point is that responsibility for ensuring compatibility between a Member State's obligations under EU law and under its agreements with third countries is a matter for that Member State, on the basis of the primacy of EU law and the duty of sincere cooperation under Article 4(3) TEU, and in line with international treaty law. In the case of agreements entered into prior to accession the $\mathrm{EU}$, which applies to some of the bilateral investment treaties in question, Article 351(2) TFEU likewise puts the responsibility on the Member State to eliminate any incompatibilities; it assumes that the Member State will remain party to the third country agreement with responsibility to bring either the incompatibility, or if necessary the agreement, to an end. ${ }^{105}$ According to the Advocate General this division of responsibility is not affected by a change in competence distribution (foreign direct investment having become exclusive EU competence). As she says,

'I can find no basis in international law (as it currently stands) for concluding that the European Union may automatically succeed to an international agreement concluded by the Member States, to which it is not a party, and then terminate that agreement. Such a rule would constitute an exception to the fundamental rule of consent in international lawmaking. ${ }^{\prime 106}$

The Court of Justice however decided that, by virtue of its now-exclusive competence over foreign direct investment as regards third countries, the EU had succeeded to the member states' third country bilateral investment treaties. Relying on its case law derived from the International Fruit Company case, ${ }^{107}$ often referred to as the doctrine of functional succession, the Court concluded that 'the European Union replaces the member states so far as concerns international commitments entered into in fields which, like that of foreign direct investment, fall within its exclusive competence' ${ }^{108}$ It thus, in contrast to the Advocate General, bases itself entirely on EU law.

It will be noted that the Court is careful to limit this ruling to foreign direct investment; as we have seen, non-direct foreign investment falls within shared competence. The Court alludes to this distinction but does not regard it as a barrier to the application of functional succession. ${ }^{109}$ Overall, although the outcome in this particular case is unexceptional, the Opinion's position on this issue is, in my view, problematic. The argument that termination of the third country bilateral investment treaties falls within exclusive Member State competence is not wholly convincing, ${ }^{110}$ but there are good reasons why functional succession has been so sparingly applied, and the Court here extends it in two ways: by applying it to Member State agreements which fall partly within shared competence, ${ }^{111}$ and by applying it in the context of revoking rather than implementing those agreements. The doctrine of functional succession is not intended to alter the international law

\footnotetext{
105 C.f. Case C-84/98 Commission v Portuguese Republic, EU:C:2000:359; C-249/06 Commission v Sweden, EU:C:2009:119.

106 Opinion of Advocate General Sharpston, para 396.

${ }^{107}$ Cases 21/72 to 24/72 International Fruit Company and Others, EU:C:1972:115, paras 10-18.

108 Opinion 2/15, para 255.

109 Note that AG Sharpston's argument was not that the content of the bilateral investment treaties, but rather that the competence to terminate them, fell within exclusive Member State competence.

110 If only because the EU has already partially regulated the continuation of these bilateral investment treaties, in Regulation 1219/2012, OJ 2012 L 351, p. 40, albeit with the proviso that the Regulation is 'without prejudice to the division of competences established by the TFEU' (Article 1(1)) .

${ }^{111}$ Earlier case law on functional succession required the EU to possess exclusive competence over the whole agreement: see e.g. case C-308/06 Intertanko, EU:C:2008:312, paras 47-52.
} 
position of third parties, but rather to express an EU law-derived obligation on the Union to respect an agreement to which it is not formally a party. The Advocate General refers in the passage quoted above to 'the fundamental rule of consent in international law-making'; ${ }^{\prime 12}$ in the International Fruit Company case (in which the Court held that the then EEC was bound by the GATT, despite not at that time being a party to the agreement) the consent of the other GATT parties, their acceptance of the EEC as an interlocutor within GATT, was an important step in its argument. ${ }^{113}$ Here too the Court refers to Singapore's consent to the clause in the Singapore Agreement, but not as a pre-condition for the operation of functional succession; instead it is given as one reason for rejecting the relevance of Article 351 TFEU: according to the Court, since Singapore has consented to the clauses in the Singapore Agreement its rights under the Member State bilateral investment treaties do not therefore need the protection which is given by Article 351 TFEU. ${ }^{114}$ This is in fact a non sequitur, since Article 351(2) TFEU actually envisages that the member states will attempt to remove any incompatibility between EU law and a prior agreement through negotiation with that third country, if necessary assisted by the other member states and (according to the Court) by the Commission. ${ }^{115}$ Indeed it is true that functional succession and Article 351 TFEU serve different purposes: whereas Article 351 TFEU allows the member states to fulfil obligations to third countries arising out of a prior (pre-accession) treaty commitments, the doctrine of functional succession is an exceptional mechanism that allows the EU, with the consent of the third country party(ies), to fulfil Member State obligations under agreements which have moved into exclusive EU competence, and provides that the agreement should be regarded as binding on the EU as a matter of EU law. Both, however, are concerned with ensuring that obligations to third countries are respected, notwithstanding transfers of competence between the EU and its member states, and neither is intended to alter the existing state of obligations under international law. They can indeed be seen as complementary. Functional succession has never been regarded as a mechanism for bringing Member State obligations towards third countries to an end. The Court's approach to the question here effectively deprives the member states of any power to manage their own existing international law obligations when a field moves into exclusive EU competence, even in cases where there is no envisaged EU external agreement; ${ }^{116}$ this is the kind of situation which may create problems for the third country and which Article 351 TFEU was designed to avoid. In practice in this particular instance, since the Member State bilateral investment treaties fall partly within shared competence, and since the intention is to replace them with the Singapore Agreement, the application of functional succession will not have a dramatic effect; however the reasoning used here would necessarily apply also to Member State agreements which fall entirely within exclusive EU competence and would be triggered irrespective of the intention of the EU to conclude a replacement. An approach more reflective of legal and practical realities would have been to accept that it was for the member states

\footnotetext{
112 See note 106.

${ }^{113}$ Cases 21/72 to 24/72 International Fruit Company and Others, EU:C:1972:115, paras 10-18.

114 Opinion 2/15, para 254.

${ }^{115}$ C-249/06 Commission v Sweden, EU:C:2009:119, para 44.

${ }^{116}$ Note that the exclusivity in question here is the a priori exclusivity of the CCP, based on Article 3(1) TFEU: it does not depend on any exercise of competence by the EU.
} 
to terminate these agreements, ${ }^{117}$ but that there is nothing to prevent them arranging for the Union to do so on their behalf, through a clause in the Singapore Agreement. ${ }^{118}$

\section{Competence in relation to ISDS}

A final issue of competence deserves a brief comment. In addition to a relatively complex but largely traditional institutional and inter-party dispute settlement structure, the Singapore Agreement contains provision for investor-state dispute settlement. Unlike the CETA, which adopts the EU's newer investment court-based form of ISDS, ${ }^{119}$ the ISDS scheme in the Singapore Agreement is based on arbitration. Generally speaking, institutional and dispute settlement provisions designed to ensure the effective implementation of substantive obligations will be regarded as ancillary, and will therefore 'follow' the competence distribution of the substantive provisions and share their legal basis. ${ }^{120}$ Although the Advocate General applied this reasoning also to the ISDS scheme, ${ }^{121}$ the Court did not. Under the terms of the Singapore Agreement the member states (and indeed the EU) are deemed to consent to investor-state arbitration, and as a result a Member State would be unable to oppose the decision of an investor-claimant to submit a dispute to arbitration. According to the Court,

'Such a regime, which removes disputes from the jurisdiction of the courts of the Member States, cannot be of a purely ancillary nature ... and cannot, therefore, be established without the Member States' consent.' ${ }^{122}$

The Court goes on to hold that competence in relation to ISDS in the Singapore Agreement is not exclusive to the EU but shared. ${ }^{123}$ This does not differ in result from a finding that ISDS is ancillary to the substantive obligations on investment, since as we have already seen competence as regards non-direct investment protection is also shared. But one result of the Court's refusal to treat the ISDS provisions as ancillary to the substantive obligations is that they then need a legal basis in their own right, and the Court surprisingly makes no mention of what this legal basis might be. ${ }^{124}$ Presumably the legal basis would reflect that of the substantive provisions (that is, Article 207 TFEU for direct investment and Article 63 TFEU for non-direct investment), but the omission is odd given that allocation of competence normally follows legal basis.

In the passage just quoted the Court says that the 'consent' of the member states is required. Might this signal that the member states need to be party to the agreement insofar as it contains provision for ISDS, on the ground that ISDS vis-à-vis the member states is a matter of (exclusive) member state

\footnotetext{
${ }^{117}$ Either on the basis of Article 351 TFEU in the case of agreements concluded prior to EU accession, or on the basis of the general duty of sincere cooperation found in Article 4(3) TEU, in the case of later agreements.

${ }^{118} \mathrm{C}$.f. the agreements on air services negotiated by the Community with a number of third countries aimed at replacing some provisions of bilateral member state agreements to bring them into line with EU law; for one example among many, see Agreement between the European Community and the Government of the Republic of Singapore on certain aspects of air services OJ 2006 L 243/21.

${ }^{119}$ And which is the subject of Opinion 1/17, pending, see note 17 .

${ }^{120}$ See e.g. Opinion 2/15 paras 275-276.

${ }^{121}$ Opinion of AG Sharpston, paras 525-526.

122 Opinion 2/15, para 292.

${ }^{123}$ Opinion 2/15, para 293.

${ }^{124}$ A point made by D Kleimann and G Kübek, note 25 .
} 
competence whereas ISDS vis-à-vis the EU is a matter of (exclusive) EU competence? ${ }^{125}$ This would result in shared competence over ISDS, but of a different type from that applying to non-direct investment. ${ }^{126}$ However in the final statement of its Opinion, the Court does not distinguish between different types of shared competence and it is unlikely to have intended to do so here. Indeed, this is not one of the passages in the Opinion where the Court concludes that the agreement 'cannot be approved by the EU alone'. Shared competence, then, does not necessarily require member state participation; the member states may consent to the agreement being concluded by the EU alone, if it is their political choice not to insist on a mixed agreement. As mentioned above, the 'clarification' which followed Opinion 2/15 over the need for a mixed agreement in all cases of shared competence, should apply also to shared competence over ISDS. ${ }^{127}$

\section{Conclusion}

This is an important Opinion which consolidates and builds upon the Court's existing rulings on the scope and reach of the post-Lisbon common commercial policy. We see the Court undertaking a detailed examination of every aspect of the agreement before it, testing each element to see whether it falls within the common commercial policy, and if not, whether exclusive competence can nonetheless be construed on the basis of Article 3(2) TFEU. What conclusions may we draw?

Taking the Opinion as a whole, there are certainly welcome clarifications and an encouraging consistency of approach to both the scope of the post-Lisbon common commercial policy and to exclusivity derived from the existence and character of EU legislation. It is also possible to understand better the interplay between an express external competence such as the CCP and what the Treaty refers to as 'the external dimension of other policies'.

The Court's approach to the scope of the CCP is expansive, and based on a test which is flexible and capable of encompassing the broader objectives mandated by the Lisbon Treaty. This approach to the CCP is, on the one hand, pragmatic in the light of evolving trade policy priorities and objectives; on the other hand, it will not always be easy to predict the result of applying the test in a specific case. The Advocate General, in fact, applied the same test and arrived at different results on several key issues. Although the Court's Opinion gives clear guidance on allocation of competence for the current model of EU trade agreement exemplified by the Singapore Agreement, in other contexts we are likely to see new disagreements over whether specific provisions will have 'direct and immediate effects' on trade.

The Court does not, in the end, find that every aspect of this current generation of comprehensive trade agreements exemplified by the Singapore Agreement falls within exclusive EU competence. Most of the agreement (including transport services) falls within exclusive competence, but the Court draws the line at non-direct foreign investment and the institutional and dispute settlement

\footnotetext{
${ }^{125}$ Note that the Court does not address the question of competence as regards ISDS vis-à-vis the EU; competence in relation to ISDS claims against the EU must fall within EU competence, and the issue is compatibility not competence; as already mentioned, the Court discusses only competence, and not compatibility: see Opinion 2/15, para 290.

${ }^{126}$ See text at note 95.

${ }^{127}$ See text at note 102 .
} 
provisions relating to these commitments, including ISDS. The practical consequences of this ruling in terms of the shaping of future trade agreements will depend on the assessment of the political institutions: should the investment protection provisions be separated from the body of the agreement, or should the agreement be concluded as mixed, with all that entails in terms of drawnout (and uncertain) national ratification? From the perspective of international investment law and standard bilateral investment treaties the division between direct and non-direct foreign investment, while a consequence of the drafting of the EU Treaties, is not intuitive. And of course the major question of the compatibility of ISDS with EU law is still open. So in this Opinion, as in Opinion 1/94 before it, the Court does not simply accept that the CCP can be used as a basis for whatever is included within a current trade agreement 'package'. Despite its readiness to accept a broad interpretation of the CCP and a broad exclusive competence - going further than the Advocate General in this respect - its interpretation of the CCP is in the end bounded by the words of the Treaties, and this is a competence field in which the Treaty text is likely to lag behind the realities of international trade policy.

Although the Court does not overtly address these questions or consequences (and one would not expect it to do so), it seems to have recognised that as a matter of practice the member states will insist on participation in major trade agreements where competence is shared (it is difficult to see a future EU-UK trade agreement being anything other than mixed). We can only be grateful that its actual words - that in the case of shared competence the agreement 'cannot be approved by the European Union alone' - have been explained as referring to this political reality rather than legal necessity. A more literal reading, while seeming to defend the member states' prerogatives, would have led to a more polarised and less flexible position in which either EU competence is exclusive or Member State participation is essential: a retrograde step, encouraging contested claims of exclusive competence in many cases where the member states are currently happy to accept that agreements in cases of shared competence can be concluded by the EU alone, and as a result competence battles are unnecessary. The ruling in respect of the termination of Member State bilateral investment treaties appears on its face to be of lesser importance, in the sense of applying to a rather specific situation, but in fact in its implications for existing Member State agreements with third countries which may become - if only in part - covered by EU exclusive competence, it is also capable of carrying significant consequences. It would be regrettable if the member states were no longer able to handle the transitions and adjustments required by these shifts of competence, through Union action where appropriate.

The way the Court uses the general external objectives found in Article 21 TEU to influence its interpretation of the CCP carries important implications. In earlier cases these objectives have been referred to as establishing a general policy framework for external policy as a whole, ${ }^{128}$ as well as for specific policy fields such as development or the CFSP, ${ }^{129}$ and as requiring fundamental rights compliance. ${ }^{130}$ Opinion 2/15 confirms the potential of Article 21 TEU to play a real role in shaping not only the practice of EU external policy but also the boundaries of its external competence. Here the general objectives become an essential step in the argument on the scope of application of Article

\footnotetext{
${ }^{128}$ Case C-660/13 Council v European Commission, EU:C:2016:616, para 39; Case C-455/14P H v Council of the European Union, EU:C:2016:569, para 41.

${ }^{129}$ Case C-377/12 European Commission v Council, EU:C:2014:1903, para 18; Case C-598/16 P Viktor

Fedorovych Yanukovych v Council, EU:C:2017:786, para 61.

${ }^{130}$ Case C-263/14 European Parliament v Council, EU:C:2016:435, para 47.
} 
207 TFEU. Instead of finding that the non-trade objectives of the Singapore Agreement were ancillary to the (predominant) trade objectives, the Court brought the non-trade objectives within the scope of the CCP. This gives them a more central status - indeed one that is reflected in the current EU trade strategy ${ }^{131}$ - and, together with its reference to 'free and fair trade' in Article 3(5) TEU, demonstrates the Court's willingness to see CCP powers used to develop a more value-driven trade policy. ${ }^{132}$ For better or worse (and views will certainly differ), this is a trend which is likely to foster the injection of politics into trade policy.

${ }^{131}$ See e.g. the Commission's most recent trade strategy paper, 'Trade for all - Towards a more responsible trade and investment policy', 14 October 2015.

${ }^{132}$ See also Decision of the European Ombudsman in case 1409/2014/MHZ on the European Commission's failure to carry out a prior human rights impact assessment of the EU-Vietnam free trade agreement. 